\title{
DYNAMICS OF PHYTOPLANKTON DISTRIBUTION IN RELATION TO STRATIFICATION AND WINTER PRECIPITATION, FALLEN LEAF LAKE, CALIFORNIA
}

\author{
Paula J. Noble ${ }^{1}$, Sudeep Chandra ${ }^{2}$, and David K. Kreamer ${ }^{3}$
}

\begin{abstract}
Seasonal succession and interannual variation of modern diatom populations in Fallen Leaf Lake, Sierra Nevada, California, are characterized and discussed in relation to stratification, water quality, and inflow during spring runoff. Fallen Leaf Lake is a deep, transparent subalpine lake that undergoes a 5-6 month period of stratification and develops a deep chlorophyll maximum (DCM) dominated by diatoms. A seasonal succession was observed, where the early spring was dominated by Asterionella formosa, Fragilaria tenera-group (F. tenera and F. nanana), Tabellaria flocculosa strain IIIp, Aulacoseira subarctica, and Urosolenia eriensis. Asterionella formosa and T. flocculosa strain IIIp persisted into the summer, becoming dominant components of the DCM. In late summer, Cyclotella rossii succeeded the araphids in the DCM and persisted until deep mixing in the late fall. In winter, the lake is ice free and well mixed, and Au. subarctica was abundant in surface waters, along with Nitzschia and the other components of the spring bloom. Strong species partitioning occurred between the epilimnion and hypolimnion, and Handmannia bodanica was the dominant summer epilimnetic diatom in all years. During a 3-year period, we observed interannual variation in the species of dominant phytoplankton. These years also varied in the depth and development of stratification, development of snowpack in the watershed, and timing of spring melt. The maximum depth of the epilimnion ranged from 12.5 to $17.5 \mathrm{~m}$, and the DCM varied from 30 to $40 \mathrm{~m}$ deep. The weakest epilimnetic development was associated with 2011 , a year with unusually deep snowpack, wintery spring conditions, and late melting. During 2011, Fragilaria tenera-group dominated the phytoplankton, and water clarity was low. A considerable portion of dead lotic diatoms were suspended in the water column, washed in from higher in the watershed during spring runoff. The lotic fraction is a significant portion of surface sediments and may be a useful proxy for identifying past changes in inflow. In addition, ratios of H. bodanica and C. rossii are explored as a possible proxy for strength in stratification. Collectively, these data provide a solid picture of the seasonal and interannual dynamics of the modern lake system, an essential step in evaluating the climate potential of the diatom record, which is currently being analyzed from lake cores.
\end{abstract}

RESUMEn.-La sucesión estacional y la variación interanual de las poblaciones modernas de diatomeas en Fallen Leaf Lake, Sierra Nevada, California, se describen y caracterizan en relación a la estratificación, la calidad del agua y la afluencia durante la escorrentía de primavera. Fallen Leaf Lake es un lago profundo, subalpino y transparente que pasa por un período de estratificación de entre 5 y 6 meses, y desarrolla un máximo profundo de clorofila $(D C M)$ en el que predominan las diatomeas. Se observó una sucesión estacional en donde durante la primera etapa de la primavera predominó la especie Asterionella formosa, el grupo Fragilaria tenera (F. tenera y F. nanana), Tabellaria flocculosa de la variedad strain IIIp, Aulacoseira subarctica y Urosolenia eriensis. Asterionella formosa y T. flocculosa de la variedad strain IIIp permanecieron durante el verano y fueron los componentes principales del DCM. En la última etapa del verano, Cyclotella rossii reemplazó a araphids en el DCM y persistió hasta la dilución en aguas profundas al finalizar el otoño. En el invierno, el lago no tiene hielo y la dilución es completa, se encontró gran abundancia de Au. subarctica en las aguas superficiales, junto con Nitzschia y los demás componentes característicos del inicio de la primavera. La división más desarrollada de especies se produjo entre el epilimnion (parte superior más cálida) y el hypolimnion (parte más fría), y Handmannia bodanica fue la diatomea predominante del verano en el epilimnion en todos los años. Durante un período de tres años, observamos la variación interanual en la especie del fitoplancton predominante. A lo largo de estos años también variaron la profundidad y el desarrollo de la estratificación, la acumulación de nieve en la cuenca y el momento del deshielo en primavera. Se observó que la máxima profundidad del epilimnion oscilaba entre 12.5 y $17.5 \mathrm{~m}$, y el $D C M$ varió entre 30 y $40 \mathrm{~m}$. de profundidad. El desarrollo más débil del epilimnion se registró en el año 2011 , cuando se produjeron fenómenos poco habituales: gran acumulación de nieve, temperatura invernal en primavera y deshielo tardío. Durante el 2011, el grupo Fragilaria tenera predominó en el fitoplancton y el agua se enturbió. Se encontró una cantidad considerable de diatomeas de agua dulce muertas suspendidas en la columna de agua, provenientes de la cuenca durante la escorrentía de primavera. La fracción lótica de agua es una cantidad significativa de sedimentos que se acumulan en la superficie y puede ser un indicador útil para identificar cambios anteriores en la afluencia de agua. Además, se estudió la relación entre H. bodanica y C. rossii como un posible indicador de la fuerza de estratificación. En términos generales, se puede decir que esta información brinda una idea clara de la dinámica estacional e interanual del sistema moderno de lagos, lo cual es un paso fundamental para evaluar el potencial del clima para el registro de diatomeas, que en la actualidad, se está analizando a través de material extraído del núcleo del lago.

\footnotetext{
1Department of Geological Science and Engineering, University of Nevada, Reno, NV 89557. E-mail: noblepj@unr.edu

${ }^{2}$ Department of Natural Resources and Environmental Science, University of Nevada, Reno, NV 89557.

${ }^{3}$ Department of Geoscience, University of Nevada, Las Vegas, NV 89154-4010.
} 
Seasonal and vertical distributions of phytoplankton in deep subalpine temperate lakes are known to follow predictable patterns influenced largely by physical structure and nutrient availability (Reynolds 1980, 1984, Sommer 1985). Interannual variations in the strength and onset of these patterns, as well as variations in the dominant taxa, are of particular interest because they form the basis for interpreting diatom-based paleoclimate records in these lake systems. A limnological monitoring program was established in Fallen Leaf Lake, Sierra Nevada, California, with the goal of providing baseline data on the ambient phytoplankton community, including vertical and temporal distribution, for ongoing paleolimnological research. Fallen Leaf Lake is a deep suboligotrophic lake in the Tahoe watershed that has become the subject of research focus because of its strong potential for producing a high-quality paleolimnological record for the Holocene. Previous limnological studies have provided shapshots of the water quality and phytoplankton in the 1970s through the early 1990s (Goldman 1970, Fuller 1975, Goldman et al. 1983, Reuter et al. 1990, 1993, 1996), but these studies were short-lived and did not explore the differential distribution of taxa throughout the water column, particularly in response to seasonal succession, stratification, and nutrient distribution. The objective of this study was to delineate the seasonal and vertical distribution of diatom phytoplankton in Fallen Leaf Lake as an initial step in interpreting the sedimentary diatom record in cores taken for paleoclimate studies. We present data collected over a 3-year period in 2009-2012 and discuss these data in relation to physiological properties, attendant water quality data, and interannual variation in winter precipitation and spring weather conditions. We use the enumeration of diatoms at discrete depths in the water column combined with comparisons to vertical composite plankton tows to discern strong partitioning in response to stratification, and we examine how partitioning may influence the relative abundance of species exported to the sedimentary record.

\section{Methods \\ Location}

Fallen Leaf Lake is a temperate subalpine lake (1950 m asl) that is $50 \mathrm{~m}$ above Lake
Tahoe (Fig. 1). Located at the base of the Glen Alpine glacial valley, Fallen Leaf Lake is dammed at its northern end by a series of recessional moraines (Brothers et al. 2009). The lake basin is steep-sided on all but the northern end, and the littoral zones are sandy with no visually apparent large masses of periphyton. The lake has a maximum depth of $120 \mathrm{~m}$, a mean depth of $70 \mathrm{~m}$, and a surface area of $5.2 \mathrm{~km}^{2}$. The watershed $\left(42 \mathrm{~km}^{2}\right)$ is approximately 8 times larger than the lake's surface area, and roughly $80 \%$ of the input is derived from snowpack (Hanes 1981). Inflow is principally through Glen Alpine Creek at the southern end of the lake. Outflow occurs at the northwest end of the lake through Taylor Creek and subsurface flow through porous moraines. Outflow then drains into the south end of Lake Tahoe (Kleppe 2005).

\section{Field Methods}

Physical, chemical, and biological characteristics were measured on a monthly basis in 2009 (1 June-10 November) and on a seasonal basis in 2010 (1 July, 10 September) and 2011 (21 June, 2 September). Physical measurements included clarity measured with a $20 \mathrm{~cm}$ diameter white Secchi disc, as well as thermal and chemical profiles (temperature, dissolved oxygen, conductivity) measured with a YSI-85 for all sample periods. Water for chemical analysis and plankton identification/enumeration was sampled from the epilimnion and the hypolimnion at 12 discrete depths $(0,3,5,7.5$, $10,12.5,15,17.5,20,25,40$, and $50 \mathrm{~m}$ ) by use of a 2-L Van Dorn sampler. $\mathrm{pH}$ was measured to $4 \mathrm{~m}$ on 27 July 2009 , and alkalinity at selected depths was measured on 27 July 2009 and 28 August 2009 in the field with a Hach titration kit (Table 1). We obtained both surface and vertical phytoplankton tows by using a $15 \mathrm{~cm}$ diameter, $20 \mu \mathrm{m}$ mesh net, with the vertical tow sampling from $70 \mathrm{~m}$ depth to the surface. We sampled the upper $20-30 \mathrm{~cm}$ of the lake by using surface tows, wherein we dragged the net behind a boat for approximately $100 \mathrm{~m}$, with the mouth of the net positioned a few centimeters below the water surface. An additional surface plankton tow was taken on 24 April 2009 during our initial reconnaissance of the lake, and the results provided useful early-season data. Also, an unusually dry December made it possible to conduct a vertical plankton tow in January 2012. 


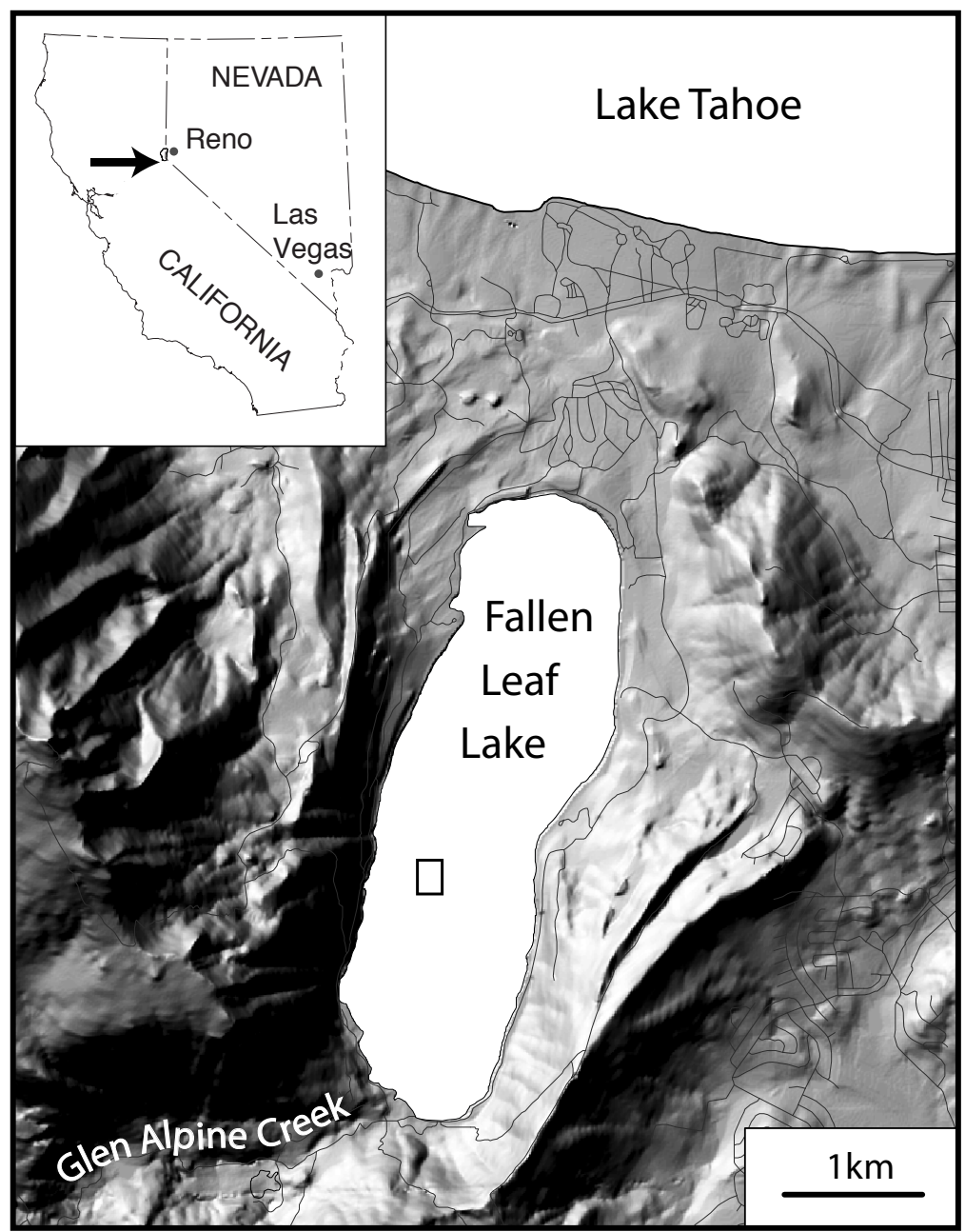

Fig. 1. Map of Fallen Leaf Lake, Sierra Nevada, California. A rectangle marks the monitoring station, located over the deepest part of the lake (120 m deep).

\section{Laboratory Analyses}

Water samples were cooled and processed within $3 \mathrm{~h}$ of collection for algal biomass, nutrients, and phytoplankton identification/enumeration. Algal biomass and degraded algal biomass were determined by measuring chlorophyll $a$ and pheophytin pigment concentrations from $100 \mathrm{~mL}$ of water. Concentrations were determined via fluorometry (Turner Designs model 10AU Fluorometer) using the Welschmeyer (1994) method with methanol as the solvent. This method was calibrated with purchased standards (chlorophyll $a$ from Anacystis nidulans, Sigma Corp.), which were calibrated against a spectrophotometric method
(Parsons et al. 1984) for quality assurance. Macronutrients were measured using standard methods (American Public Health Association 2006; total and dissolved phosphorus-USEPA method 365.3; soluble reactive phosphorusSM4500-PE; nitrate-USEPA method 353.1; ammonia/ammonium-USEPA method 350.1). A subset of samples was analyzed for total Kjeldahl nitrogen (TKN) during 5 of the sampling periods in 2009 (1 June-25 September) by High Sierra Water Lab following USEPA method 351.2 (Table 1). Major cations were analyzed for the first 3 of the 2009 sampling periods (1 June-27 July). Samples for cations were filtered and acidified, then analyzed by Laser Ablation Inductively Coupled Mass 


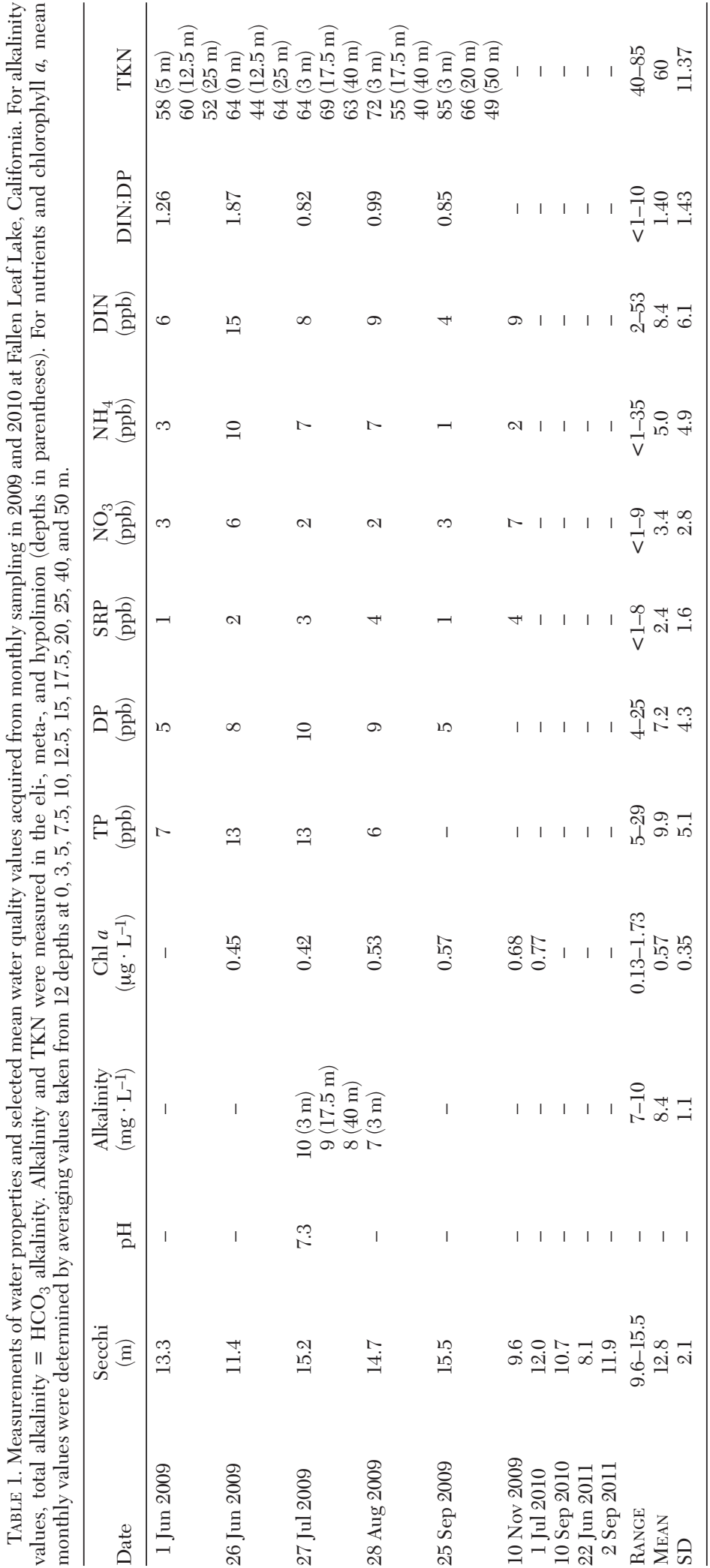




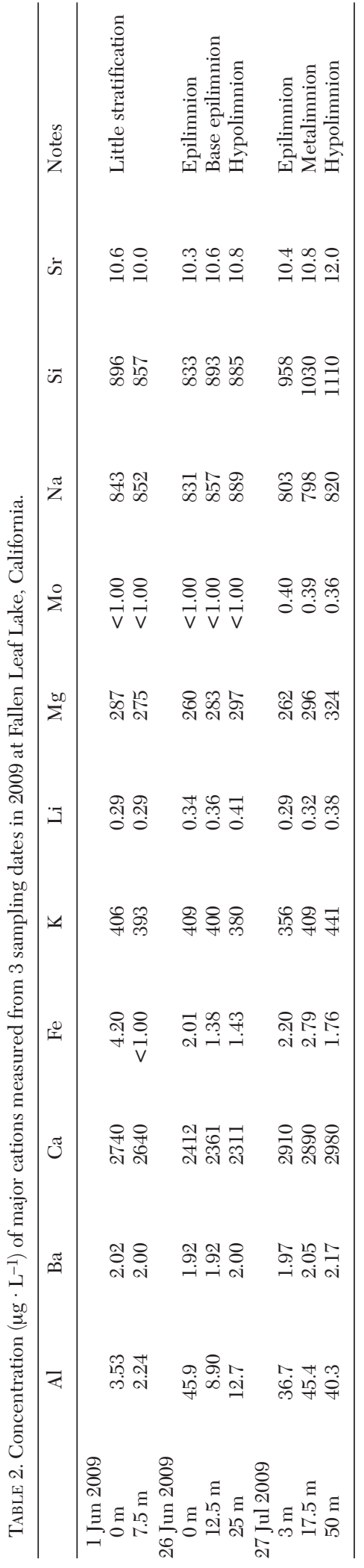

Spectrometry at the Nevada Bureau of Mines and Geology, University of Nevada (Table 2).

Lake trophic condition was quantified using a trophic state index (TSI) (Carlson 1977):

$$
\mathrm{TSI}=14.42 \ln (\mathrm{TP})+4.15,
$$

where TP is the total phosphorus concentration $\left(\mu \mathrm{g} \cdot \mathrm{L}^{-1}\right)$. Index values $>50$ indicate eutrophic conditions, and values $>70$ indicate hypereutrophic conditions (Wetzel 2001).

A 250-mL subsample of lake water from each depth was preserved by Lugol's addition. Diatom biomass was determined for water samples from 10 of the sample depths: $0,3,5,10$, $15,17.5,20,25,40$, and $50 \mathrm{~m}$ for each of the 2009-2010 sampling periods. In 2011, the 3-m sample was eliminated and one at $30 \mathrm{~m}$ was added to better capture the vertical changes in diatom communities. The $250-\mathrm{mL}$ water samples were settled and concentrated to $20 \mathrm{~mL}$, and absolute abundance was determined by counting using a gridded 1-mL SedgewickRafter counting cell at 400X magnification. A minimum of 5 rows of each counting cell $(=$ $25 \%$ of 1 -mL volume) were counted (mean $n=$ 682). Cell counts were made at the genus level for both "live" (chlorophyll and lipids present) and dead cells (siliceous frustule only). Cell counts were converted to biovolume following Hillebrand (1999). Live cells of nondiatom algal groups were noted qualitatively but not counted, the most common being chrysophytes (Dinobryon, unspecified stomatocysts), dinoflagellates (Ceratium and Gymnodinium) and chlorophytes (Botryococcus, Elakatothrix). Small amounts of picoplankton $(<6 \mu \mathrm{m})$ were also noted but were below the size limit for determination by our enumeration methods.

Permanent slide mounts were made in order to determine relative abundance counts $(n$ $>100$ ) for plankton tows and a subset of water depth samples (10, 20, and $50 \mathrm{~m}$ for 2009 samples). Permanent slides were made by drying a pipetted aliquot onto a coverslip and mounting the coverslip onto a glass slide using Zrax diatom mountant (boil mounts). These slides allowed for discrimination between live and dead material and were beneficial, along with the water samples, in differentiating between indigenous and washed-in taxa. Additional slides were made as burn mounts (USEPA 1973) and as strewn slides of siliceous slurries cleaned with hydrogen peroxide (Battarbee 
1986) in order to aid in species-level identification. Diatoms were identified using a 1000X oil immersion lens with DIC on an Olympus BX51 microscope, and counts were made at 400X. Separate counts $(n=100)$ of the cyclotelloid fraction were made at 1000X. Photomicrographs and identification notes for common taxa may be found in the Appendix.

\section{Data Analysis}

Contour plots of diatom data were generated with the "filled.contour" function in R, version 2.15.0 ( $\mathrm{R}$ Development Core Team 2012), using the interp algorithm in the package akima, version 0.5-7 (interpolation of irregularly spaced data; Akima et al. 2012). Annual precipitation data were extracted from PRISM (PRISM Climate Group 2012) for the latitude and longitude of Fallen Leaf Lake, and water-year total precipitation was calculated from 1 October of the previous year through 30 September of that year. Local annual snowfall data, collected from SNOTEL station 473 at Fallen Leaf Lake from 1980 to 2011, was accessed from the Natural Resources Conservation Services web site (NRCS 2012).

\section{REsults}

\section{Field Measurements of Water Properties}

Field measurements of water properties indicated a dilute system with a circumneutral $\mathrm{pH}$ and low alkalinity $\left(7.9-10 \mathrm{mg} \cdot \mathrm{L}^{-1}\right)$, indicating a very limited buffering capacity (Table 1). Mean conductivity was low, averaging 21 $\mu \mathrm{S}$ (Fig. 2), and analysis of major cations showed concentrations in the range of a few hundred ppb for all but calcium (Table 2). In 2009, stratification had begun by 1 June, with the base of the epilimnion expanding from a depth of $12.5 \mathrm{~m}$ to a maximum depth of $17.5 \mathrm{~m}$ by late summer (Fig. 2). Dissolved oxygen profiles in 2009 showed an offset of $1-3 \mathrm{mg} \cdot \mathrm{L}^{-1}$ at $17.5 \mathrm{~m}$, the base of the epilimnion, during the stratification months, and remixing to a minimum depth of $32 \mathrm{~m}$ in the fall (Fig. 2). Data collected in September 2010 from $40 \mathrm{~m}$ and $50 \mathrm{~m}$ showed a decrease in dissolved oxygen in the deeper hypolimnion $(>35 \mathrm{~m}$ ) but did not indicate anoxic conditions.

Interannual variations in stratification were also apparent in a comparison of the 3 years. The onset of stratification and the spring bloom was delayed in 2010 (Fig. 2) compared with
2009, owing largely to cooler spring temperatures and slower snowmelt. Although delayed, depth of stratification in 2010 eventually by the end of summer reached a depth similar to that in 2009 (17.5 m). In 2011, considerably higher winter precipitation and a deep snowpack combined with cooler spring temperatures resulted in delayed stratification and considerably shallower epilimnion development, which reached a depth of only $12.5 \mathrm{~m}$ by early September 2011.

Water clarity and chlorophyll $a$ concentrations indicate the lake is presently oligotrophic, and nutrient concentrations are consistent with $\mathrm{N}$-limitation (Table 1). The trophic state index calculated from surface TP measurements is 22-37, which suggests the lake is oligotrophic (Carlson and Simpson 1996). Secchi disk and chlorophyll $a$ measurements also indicate oligotrophic conditions. From a nutrient standpoint, average monthly values of dissolved phosphorus (DP) and its bioavailable component, soluble reactive phosphorus (SRP), were low, never exceeding $13 \mathrm{ppb}$ (Table 1). Highest values of DP were associated with the metalimnion during June and July (Fig. 3). Total phosphorus (TP) ranges from 5 to $29 \mathrm{ppb}$ with a mean value of 9.9 , indicating that the limited algal response measured by chlorophyll $a$ concentrations may be a result of nitrogen limitation (Carlson 1983). Ratios of dissolved inorganic nitrogen (DIN) to dissolved phosphorus (DP) were $<2$ and supported nitrogen limitation (Table 1); however, nutrient bioassays conducted in 2006 indicated $\mathrm{N}$ limitation in the spring, changing to $\mathrm{N}-\mathrm{P}$ co-limitation during summer and early fall (Chandra and Rost 2008). $\mathrm{NO}_{3}$ levels were slightly elevated in the spring, likely owing to dissolved inorganic nitrogen entering the lake via spring runoff from higher in the watershed (Fig. 3). Highest $\mathrm{NO}_{3}$ values in 2009, a fairly dry year, were recorded in June and did not exceed $10 \mathrm{ppb}$. In June 2011, an $\mathrm{NO}_{3}$ measurement taken in Glen Alpine Creek entering Fallen Leaf Lake during a rapid period of snowmelt had a value of $21 \mathrm{ppb}$. $\mathrm{NH}_{4}$ values were highest in late spring and summer 2009 , with one high value of 35 ppb observed in surface waters on 26 June 2009 (Table 1, Fig. 3). This value may be spurious, or alternatively may represent high activity levels by excretors. Major ion analysis also shows low levels of micronutrients, including iron, molybdenum, and silica (Table 2). The July sampling 


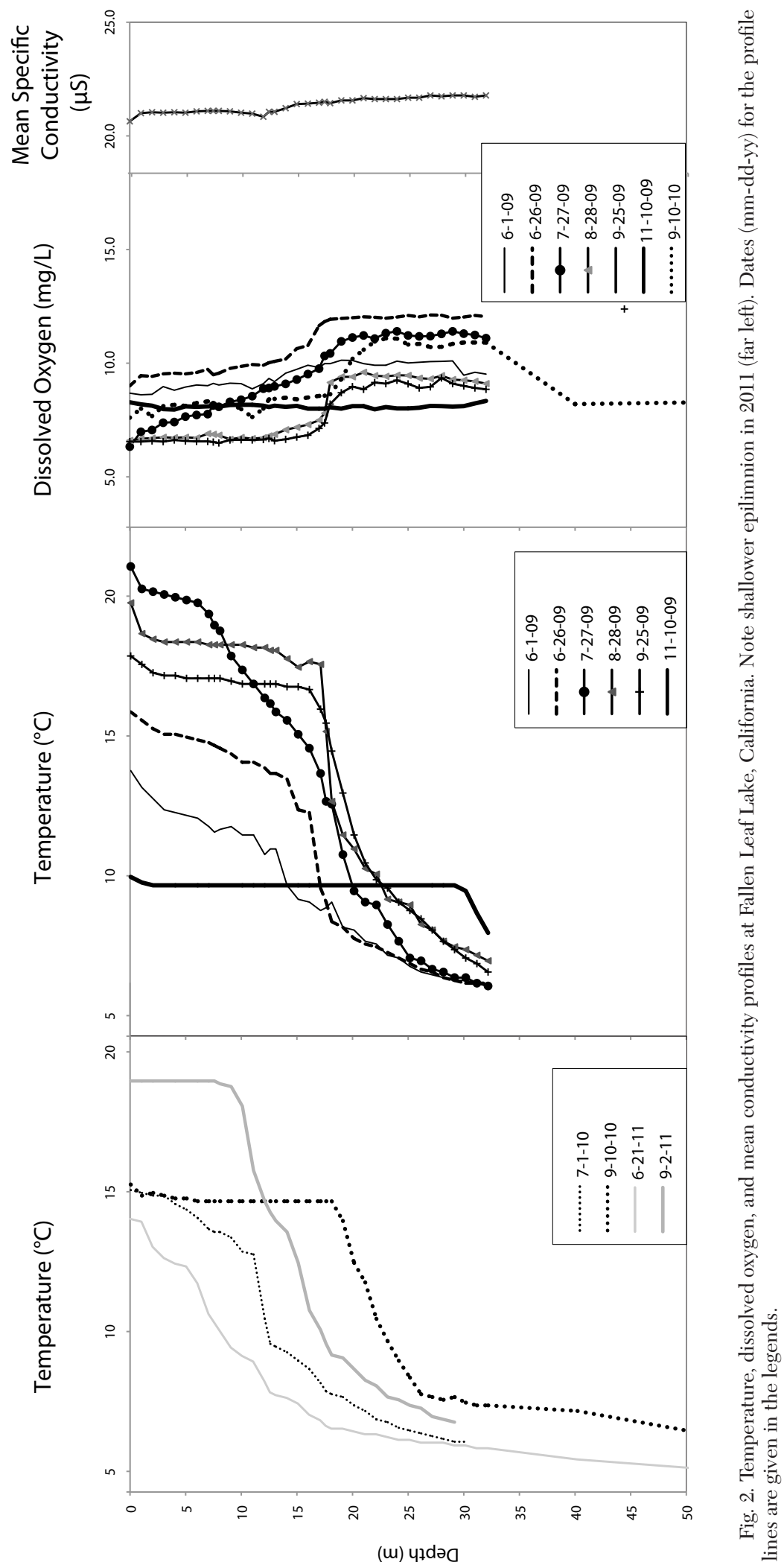



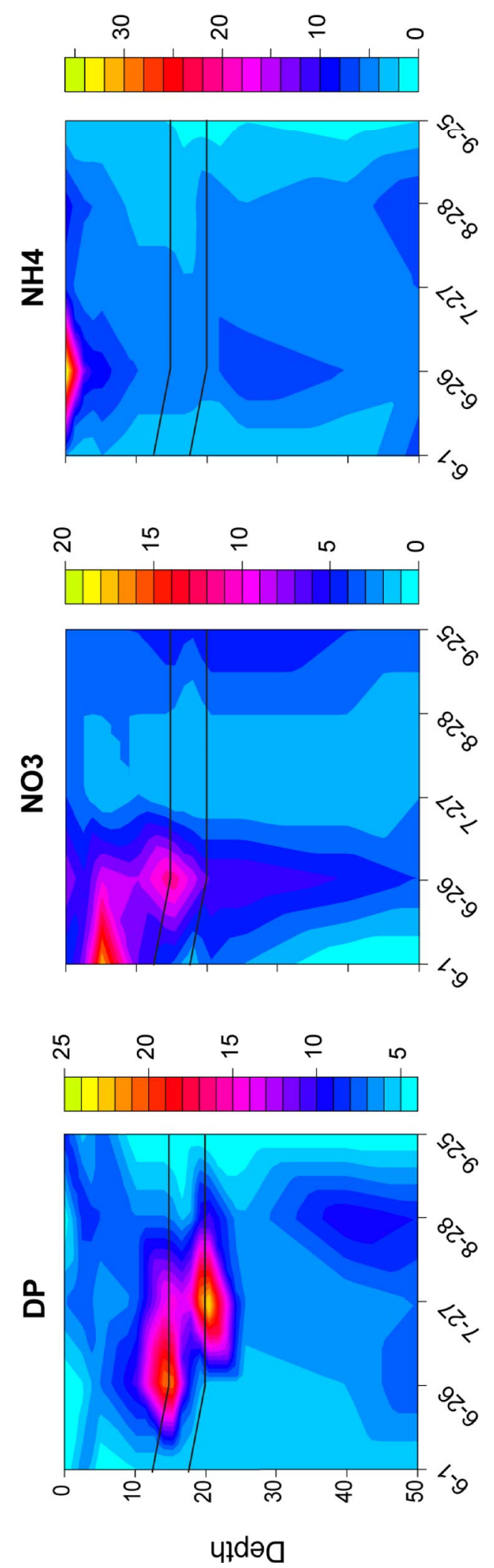

showed slight variation in silica between the epilimnion and upper hypolimnion, but overall values remained low, $\leq 1 \mathrm{ppm}$.

\section{Seasonal and Vertical Distribution from Plankton Tows}

Surface plankton tows from April to November 2009 indicated a seasonal diatom succession of Aulacoseira subarctica + Nitzschia spp. $\rightarrow$ Asterionella formosa + Tabellaria flocculosa strain IIIp $\rightarrow$ Urosolenia eriensis + Fragilaria tenera-group $\rightarrow$ Handmannia bodanica. Aulacoseira subarctica rapidly decreased in June, while araphids remained dominant throughout the spring bloom. Urosolenia eriensis and F. tenera-group had a significant peak in early June and then decreased substantially by early summer. Also present in the early spring tows were significant abundances of dead, washed-in taxa (Table 3), many of which were seen in boil mounts as dead specimens clumped with organic flotsam. Because the boil mounts preserved the chlorophyll inside the diatom frustules, it was possible to differentiate dead, washed-in taxa entrained in the water column from live taxa (Table 3). With the onset of stratification, $H$. bodanica became increasingly abundant and dominated the epilimnion in mid and late summer.

Vertical tows from 2009 provided a useful composite for comparison against the surface tows during the period of stratification (Fig. 4). Relative abundances varied markedly between surface and vertical tows, with Aulacoseira subarctica, Asterionella formosa, and Tabellaria flocculosa strain IIIp falling off dramatically in the surface yet remaining high in the composite. The tow from 25 September 2009 showed a marked vertical partitioning. For example, Handmannia bodanica, which dominated the surface tow, was grossly overshadowed by the abundance of As. formosa in the composite tow (Fig. 4). Vertical partitioning patterns were further elucidated through biovolume counts of live taxa in discrete water samples and are discussed in detail below. Results from plankton tows taken in the spring and fall of 2010 and 2011 further support these general patterns of seasonal succession

Fig. 3. Contour plots of dissolved phosphorus and $\mathrm{NO}_{3}$ concentrations $(\mathrm{ppb})$ from discrete water samples taken in 2009 at Fallen Leaf Lake, California. Position of metalimnion is shown with 2 black lines. 
TABLE 3. Diatom species observed in plankton tows and water samples from Fallen Leaf Lake, California. $\mathrm{a}=$ abundant, $\mathrm{c}=$ common, $\mathrm{r}=$ rare.

\begin{tabular}{|c|c|c|c|}
\hline Diatom species & Live & $\begin{array}{l}\text { Live, likely } \\
\text { washed in }\end{array}$ & $\begin{array}{l}\text { Dead, } \\
\text { washed in }\end{array}$ \\
\hline Acanthidium sp. & & & c \\
\hline Achnanthes peragalli & & & $\mathrm{c}$ \\
\hline Asterionella formosa & a & & \\
\hline Aulacoseira humulis & $\mathrm{r}$ & $\mathrm{x}$ & $\mathrm{r}$ \\
\hline Aulacoseira lacustris & & & $\mathrm{r}$ \\
\hline Aulacoseira lirata & & $\mathrm{x}$ & $\mathrm{r}$ \\
\hline Aulacoseira perglabra & $\mathrm{r}$ & $\mathrm{x}$ & $\mathrm{r}$ \\
\hline Aulacoseira pusilla & $\mathrm{r}$ & $\mathrm{x}$ & $\mathrm{r}$ \\
\hline Aulacoseira subarctica & $\mathrm{a}$ & & \\
\hline Cocconeis placentula & & & $\mathrm{c}$ \\
\hline Cyclotella antiqua & & & $\mathrm{r}$ \\
\hline Cyclotella cf. ocellata & a & & \\
\hline Cyclotella glomerata & & & $\mathrm{r}$ \\
\hline Cyclotella rossii & $\mathrm{a}$ & & \\
\hline $\begin{array}{l}\text { Didymosphenia } \\
\text { geminata }\end{array}$ & & & $\mathrm{r}$ \\
\hline Discostella stelligera & & & $\mathrm{c}$ \\
\hline Eunotia formica & & $\mathrm{r}$ & $\mathrm{r}$ \\
\hline $\begin{array}{l}\text { Fragiaria tenera/ } \\
\quad \text { nanana }\end{array}$ & a & & \\
\hline Fragilaria gracilis & c & & \\
\hline Fragilaria crotonensis & & & $r$ \\
\hline Fragilaria vaucheriae & & & $\mathrm{r}$ \\
\hline $\begin{array}{l}\text { Frustulia amphi- } \\
\quad \text { pleuroides }\end{array}$ & $\mathrm{r}$ & $\mathrm{x}$ & $\mathrm{r}$ \\
\hline Handmannia bodanica & a & & \\
\hline Karayevia suchlandtii & & & c \\
\hline Navicula aurora & & & $\mathrm{r}$ \\
\hline Nitzschia acicularis & $\mathrm{r}-\mathrm{c}$ & & $\mathrm{c}$ \\
\hline Nitzschia gracilis & $\mathrm{r}-\mathrm{c}$ & & $\mathrm{r}$ \\
\hline Nitzschia frustulum & & & $\mathrm{r}$ \\
\hline Nitzschia intermedia & $\mathrm{r}$ & & $\mathrm{c}$ \\
\hline Pinnularia sp. & $\mathrm{r}$ & $\mathrm{x}$ & \\
\hline Stauroneis anceps & & & $\mathrm{r}$ \\
\hline $\begin{array}{l}\text { Staurosira construens } \\
\text { v. venter }\end{array}$ & $r$ & $\mathrm{x}$ & $\mathrm{r}$ \\
\hline $\begin{array}{l}\text { Staurosira pseudo- } \\
\text { construens }\end{array}$ & & & $\mathrm{r}$ \\
\hline Staurosirella martyi & & & $\mathrm{r}$ \\
\hline Staurosirella pinnata & $\mathrm{r}$ & $x$ & $\mathrm{r}$ \\
\hline Stephanodiscus medius & $\mathrm{r}$ & & \\
\hline Tabellaria fenestrata & $\mathrm{r}$ & $\mathrm{x}$ & \\
\hline $\begin{array}{l}\text { Tabellaria flocculosa } \\
\text { strain IIIp }\end{array}$ & a & & \\
\hline $\begin{array}{l}\text { Tabellaria flocculosa } \\
\text { strain IV }\end{array}$ & $\mathrm{r}$ & $\mathrm{x}$ & \\
\hline Urosolenia eriensis & $\mathrm{a}$ & & \\
\hline
\end{tabular}

and response to stratification, although there were interannual differences in species abundances.

A 30-m vertical composite taken in January 2012 provides a valuable winter snapshot, although the winter of 2011/12 was unusually dry, with November-December 2011 precipitation at roughly $6 \%$ of the 100 -year average. There was a fair amount of organic flotsam in the plankton tow, presumably remixed from the hypolimnion, and many diatom frustules were clumped within the flotsam. Of the live taxa, the most abundant were Aulacoseria subarctica, Asterionella formosa, Nitzschia spp., and Cyclotella rossii. Live Tabellaria flocculosa strain IIIp, Handmannia bodanica, and fragilarioid chains (e.g., Staurosirella pinnata, Staurosira construens var. venter, Pseudostaurosira brevistriata) were also present in subordinate amounts. Fragilaria frustules (F. teneragroup and $F$. gracilis) were common, but most appeared to be dead or degraded cells that were likely remixed from the hypolimnion. Aulacoseira subarctica was by far the most abundant Aulacoseira species; however, live and healthy-looking filaments of Au. perglabra and Au. humilis were also found. Based on the reported autecology of these low-mantled tychoplanktonic species (Florin 1981, Camburn and Kingston 1986, Haworth 1988), it is likely that they were washed into the lake from marshy areas higher in the watershed and then resuspended when the lake was mixed in the late fall. Both Au. perglabra and Au. humilis are observed in small ponds and streams higher in the watershed. Aulacoseira pusilla and Au. lirata also occurred within the winter tow but most of these filaments appeared seriously degraded or dead.

\section{Vertical Distribution from Discrete Depth Sampling}

The chlorophyll maximum at Fallen Leaf Lake descends rapidly with the onset of stratification to form a seasonal deep chlorophyll maximum (DCM) in the hypolimnion that is roughly centered at $40 \mathrm{~m}$ (Fig. 5). Because diatoms dominate the algal populations in the spring, the chlorophyll maximum strongly correlates to the diatom maximum until late summer $(r=0.86$ for June and July), when chrysophytes and dinoflagellates become an important component of the DCM. There was a marked compositional difference between the phytoplankton of the DCM and the epilimnion, similar to other deep transparent lakes, such as Lake Tahoe (Coon et al. 1987) and the Laurentian Great Lakes (e.g., Moll and Stoermer 1982). Floral compositions in these systems may vary from year to year in terms of which species are most dominant, but the compositional distinction between the DCM and epilimnetic floras remains (e.g., Barbiero 


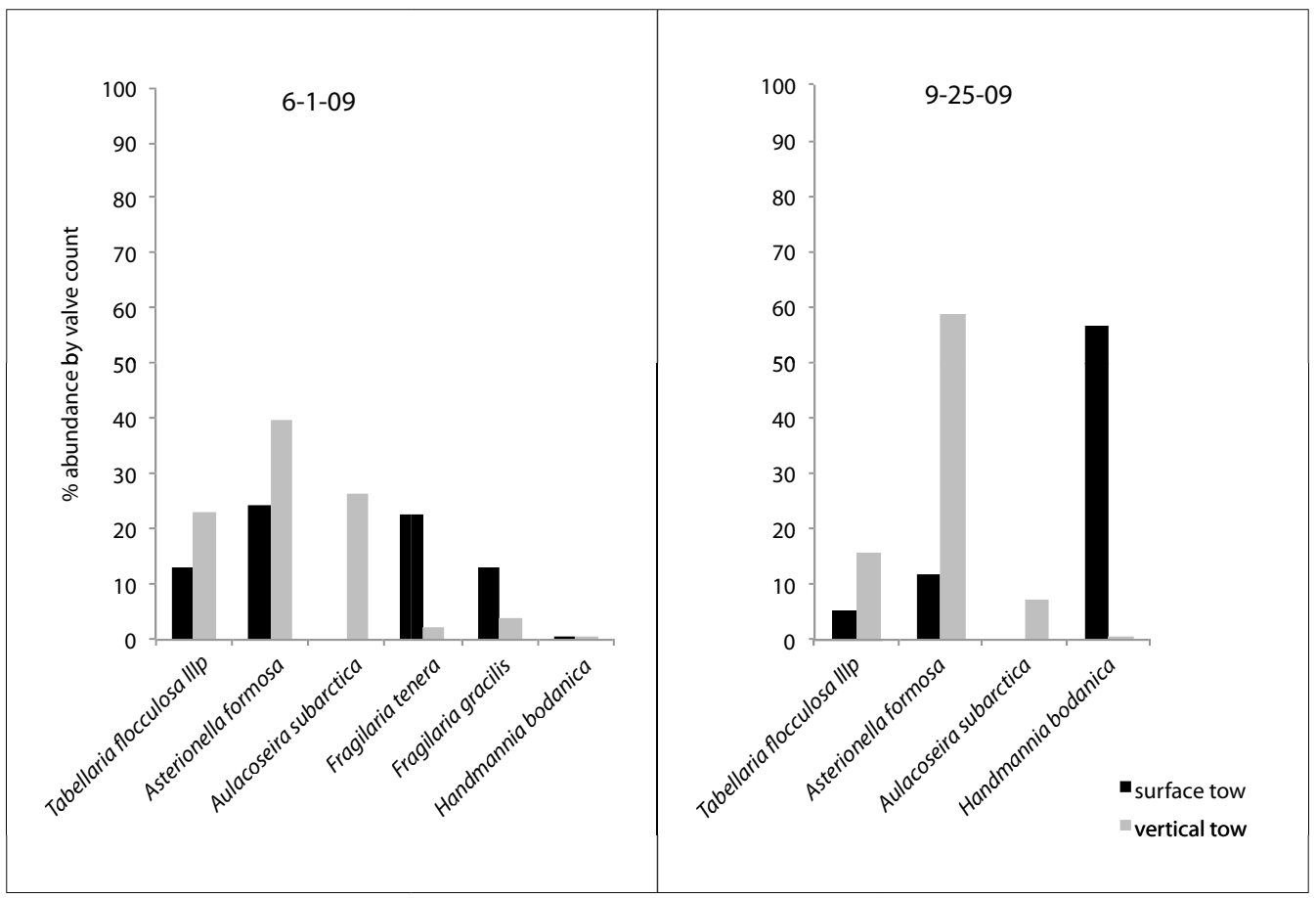

Fig. 4. Plankton tow data showing seasonal changes and variation in phytoplankton composition between the epilimnion (surface tow) and a composite water column (vertical tow) by late summer at Fallen Leaf Lake, California. Species shown are those with >1\% abundance during the sampling (1 Jun 2009 and 25 Sep 2009).

Date

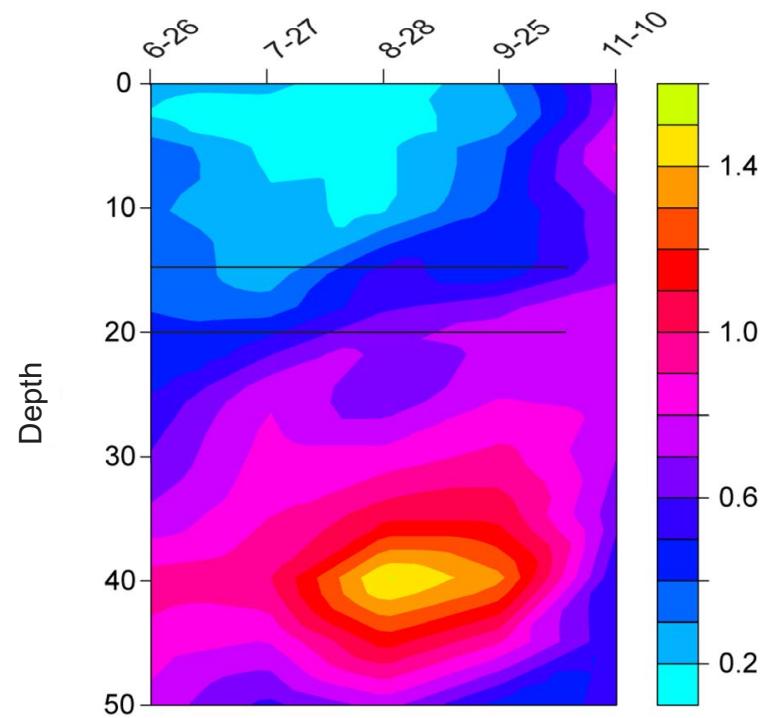

Chlorophyll $a\left(\mu \mathrm{g} \cdot \mathrm{L}^{-1}\right)$

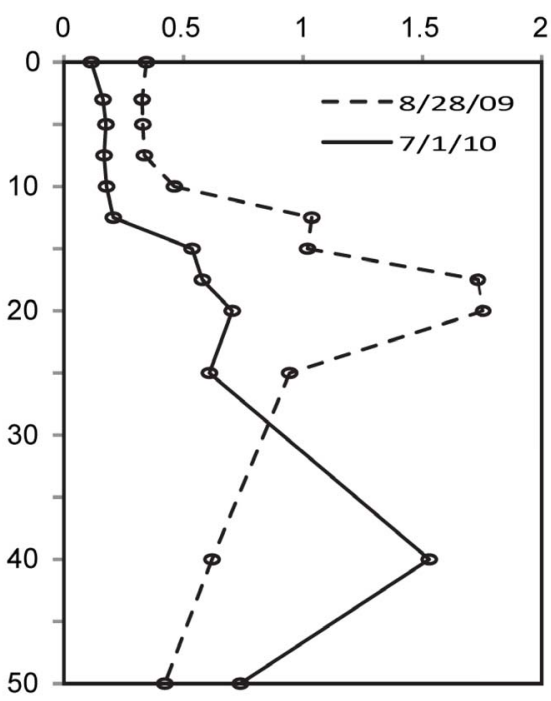

Fig. 5. Chlorophyll $a$ concentrations, phaeophytin corrected $\left(\mu \mathrm{g} \cdot \mathrm{L}^{-1}\right)$, showing position of the chlorophyll maximum at Fallen Leaf Lake, California. Left: Contour plot of 2009 data. Position of metalimnion is shown by 2 black lines. The DCM at 40 m reached maximum intensity in August. Right: Vertical profiles of chlorophyll $a$ from late season 2009 compared with early season data collected in 2010 showing downward migration of the DCM. 


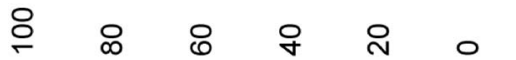

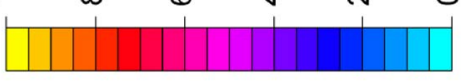
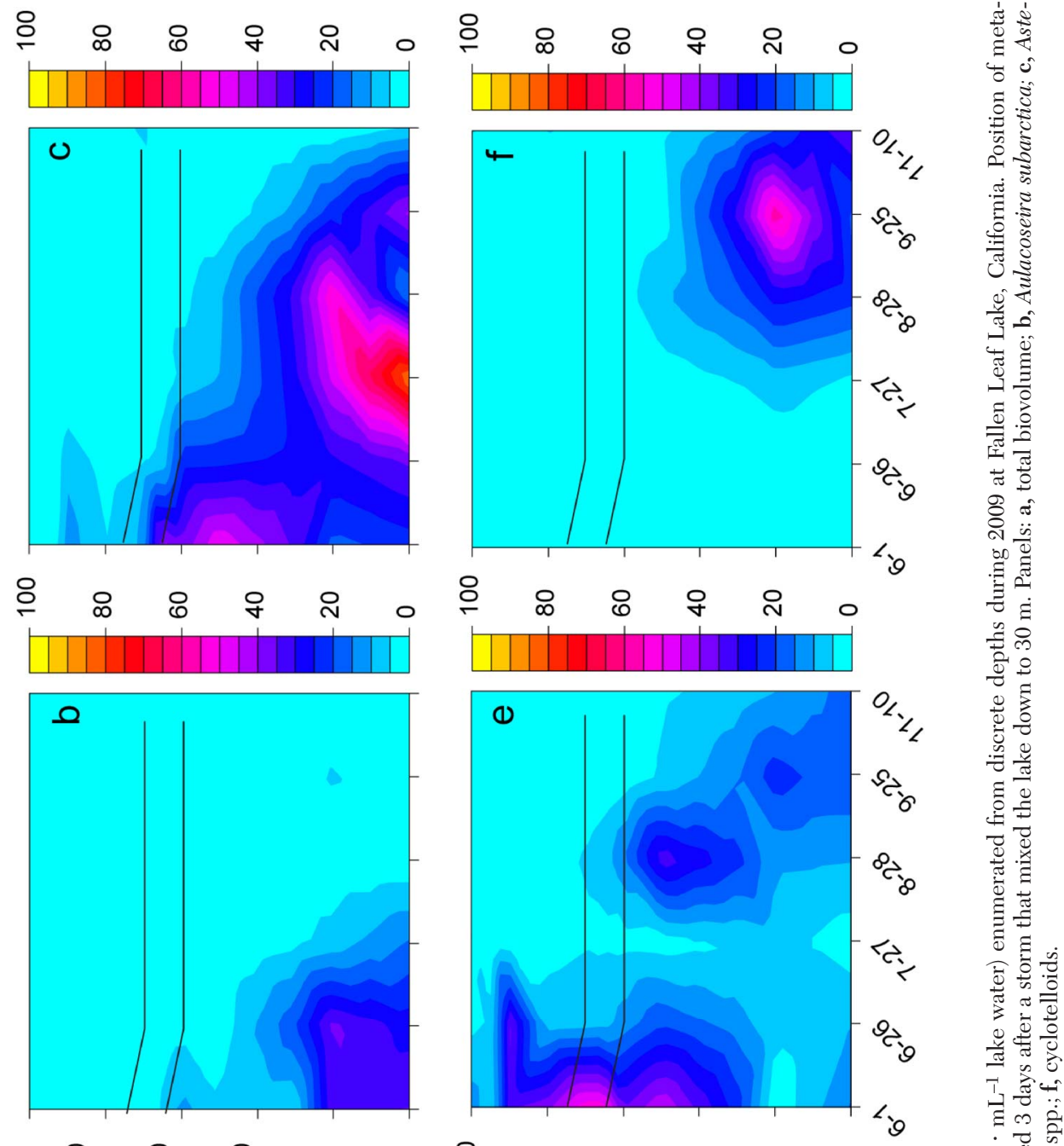

8.
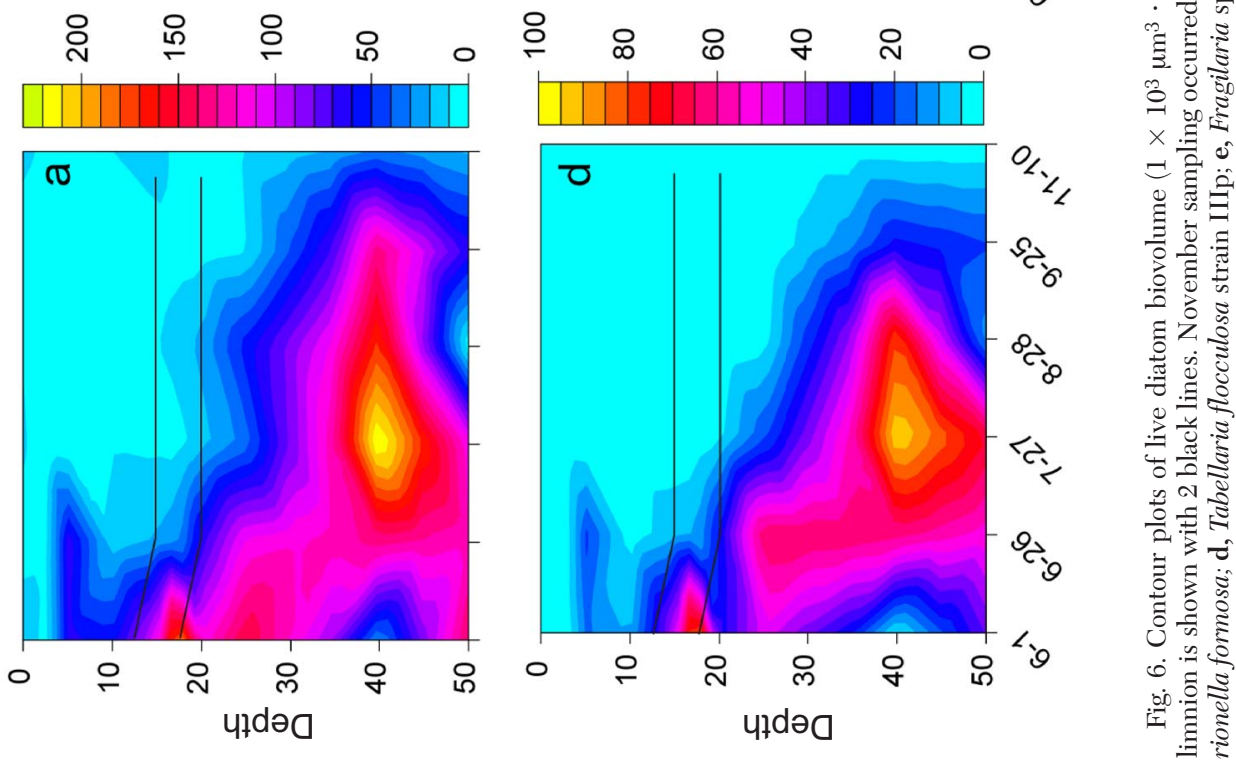
and Tuchman 2004). In Fallen Leaf Lake, several species found in abundance at the surface in early spring (Aulacoseira subarctica, Asterionella formosa, Tabellaria flocculosa strain IIIp) showed a "push down"; namely, peak abundances occurred at progressively deeper levels as seasonal stratification progressed (Fig. 6). Like the epilimnion, the DCM undergoes a seasonal succession, where Au. subarctica, a prominent DCM component in the early spring, was surpassed by Asterionella and Tabellaria in the later spring, and followed by Cyclotella rossii, plus chrysophytes and dinoflagellates in the late summer.

Several species peaked outside of the DCM, contributing to compositional differences between the DCM and epilimnion. Urosolenia eriensis and Fragilaria tenera-group, species found in high abundance in the surface only during the spring bloom, drop markedly in abundance in the summer. Fragilaria spp. (e.g., F. gracilis) remain a significant part of the epilimnion throughout the summer, and their maximum abundance is consistently found in the upper hypolimnion $\sim 10-15 \mathrm{~m}$ above the DCM (Fig. 6). During the summer, the epilimnion is depleted in algal biomass and is dominated largely by Handmannia bodanica and Dinobryon. Handmannia bodanica appears to be well adapted to the warmer lower-density water of the epilimnion and seems unaffected by the high UV intensity. Handmannia bodanica did not have a specific peak abundance in the epilimnion, but the species composes a higher percentage of the epilimnion because of the reduction in other species. Overall, the effect on and control over the formation and intensity of the DCM are significant in Fallen Leaf Lake because the DCM is where the maximum production of diatoms occurs, and has a strong influence on the diatom biovolume exported to the sediment.

\section{DisCUSSION}

\section{Deep Chlorophyll Maximum}

There has been some discussion over factors controlling the formation and position of deep chlorophyll maxima, including UV inhibition effects, nutrient availability, and water density (Reynolds 1992, Saros et al. 2005, Camacho 2006, Harrison and Smith 2011). In high-elevation lakes, higher intensities, particularly of UVB radiation, have an effect on epilimnetic phytoplankton composition (Harrison and Smith 2011). These higher intensities also may explain consistently low phytoplankton numbers in the upper $5 \mathrm{~m}$ of water, particularly in the early spring before the epilimnion was fully developed. Handmannia bodanica is well suited for the epilimnion because (1) it is a good N competitor and low-N specialist (Interlandi et al. 1999), (2) it can regulate its buoyancy, and (3) it has high light requirements (Saros et al. 2003).

The seasonal and vertical distributions of the major indigenous phytoplankton may be explained by known physiological requirements for these species. Aulacoseira subarctica shows highest abundances prestratification, descending to the upper hypolimnion and maintaining its peak abundance at greater depths (40-50 m) than other species (Fig. 6). A similar seasonal response of Au. subarctica has been observed in other temperate lakes and has been explained by its high sinking rate, low water temperature tolerance, low light requirements, and higher $\mathrm{P}$ requirements (Interlandi et al. 1999, Reynolds 2006). Asterionella formosa, like Au. subarctica, is also tolerant of wintery water temperatures but has considerably lower sinking rates than $A u$. subarctica (Reynolds 1984). Although an excellent $\mathrm{P}$ competitor (Interlandi et al. 1999), As. formosa is also highly responsive to nitrogen stimulation in N-limited alpine lakes (Saros et al. 2005), and its chronic high abundances in Fallen Leaf Lake may be driven by DIN. Asterionella formosa concentrations exceeded 40 $\mu \mathrm{m}^{3} \cdot \mathrm{L}^{-1}$ in the DCM in all 3 years during peak growth. Cyclotelloids, in general, are considered good N competitors, with good buoyancy regulation and low growth rates (Saros et al. 2003), all of which help explain the observed Cyclotella rossii growth peak in the DCM in late summer. The maximum intensity of the DCM was in late August, resulting from a combination of increased abundances of dinoflagellates and chrysophytes, residual standing crops of Tabellaria flocculosa strain IIIp, and increased growth of C. rossii to $>50$ $\mu \mathrm{m}^{3} \cdot \mathrm{L}^{-1}$ (Fig. 6).

\section{Nutrients and Phytoplankton Distribution}

Distribution patterns of nutrients support the idea that the observed spring bloom intensity is in part governed by nutrient stimulation entering the lake during runoff. Dissolved inorganic nitrogen is expected to have the 

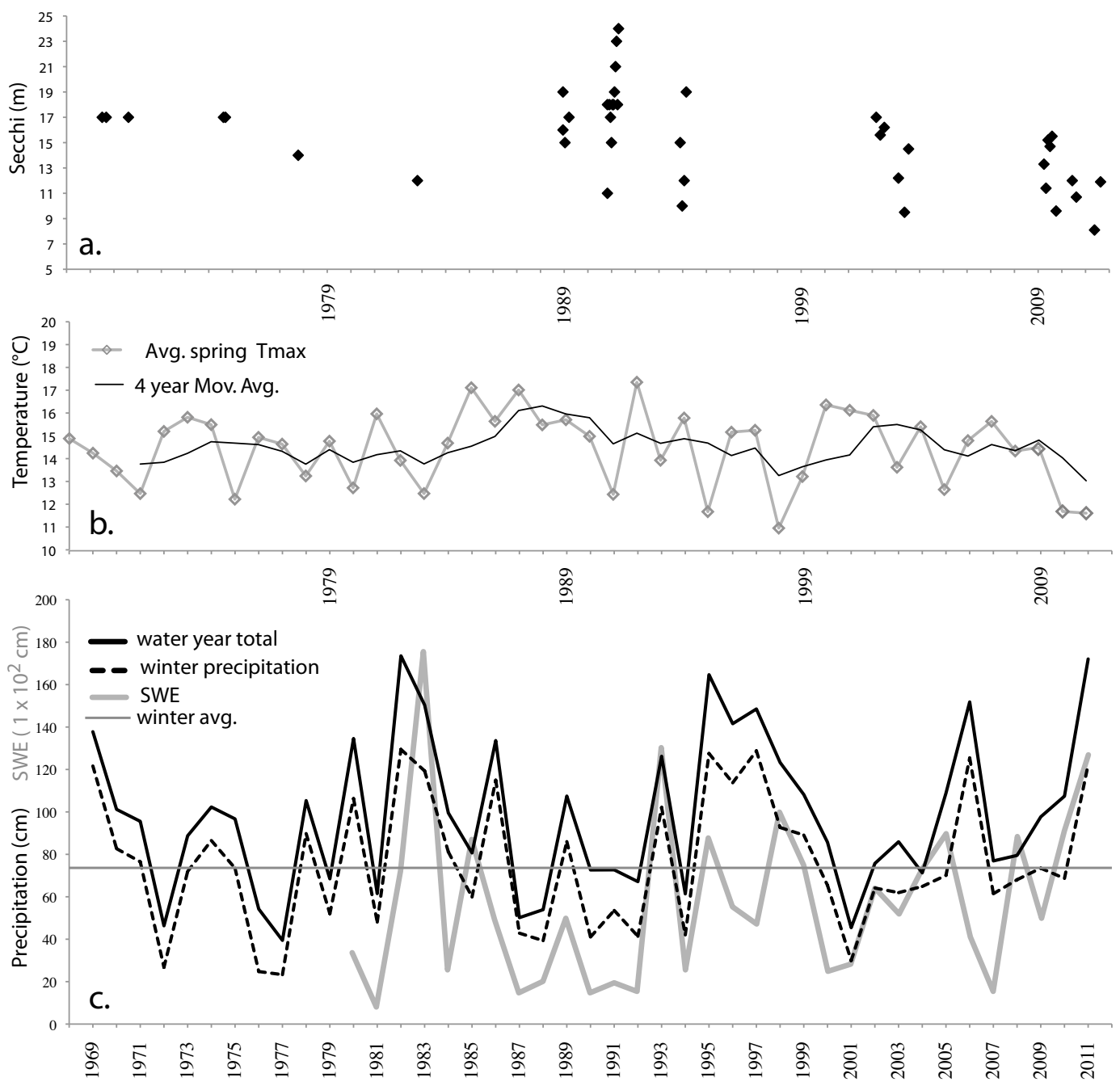

Fig. 7. Precipitation, temperature, and historical transparency data for Fallen Leaf Lake, California, from 1969 to 2011: a, Transparency data plotted from values summarized in Reuter et al. (1996) for 1969-1994, Lico (2004) for 2002-2003, and this study for 2009-2011; b. Average spring temperature data show a $2.9^{\circ} \mathrm{C}$ drop between 2009 and 2010-2011 spring temperatures showing lower spring temperatures for 2010 and 2011 relative to 2009; c, Precipitation data, where water year total precipitation is calculated from 1 October the preceding year through 30 September of that year, and where winter precipitation represents November through March totals. SWE $=$ the cumulative snow water equivalent recorded at SNOTEL station 473 at Fallen Leaf Lake from 1980 to 2011. The 42-year winter precipitation average is shown with a horizontal line.

greatest stimulatory effect in $\mathrm{N}$-limited systems, as indicated by numerous $\mathrm{N}$-limited systems that have experienced recent stimulatory effects from dissolved inorganic nitrogen influxes (Saros et al. 2005). In particular, the presence of Asterionella formosa has been attributed to $\mathrm{N}$ deposition in other alpine lake systems, and indeed the Lake Tahoe Basin has experienced eutrophication, with atmospheric $\mathrm{N}$ deposition accounting for $55 \%$ of the total $\mathrm{N}$ inputs (TERC 2011). Given that $80 \%$ of the precipitation in the Fallen Leaf Lake watershed originates as runoff from snowpack, it is expected that highest $\mathrm{N}$ concentrations should occur in the early spring during peak flow of Glen Alpine Creek. As mentioned previously, concentrations of $\mathrm{N}$ measured in 2009 were slightly elevated in the 1 June sampling $(12 \mathrm{ppb}$ maximum; Fig. 3) and may have potentially been higher earlier in the season, before our 
sampling program had been established. The 2011 year experienced an unusually deep snowpack and low spring temperatures, and ice-out dates for several of the surrounding lakes were a full month behind the previous year (Fig. 7). Nutrient concentrations in Glen Alpine Creek, $0.5 \mathrm{~km}$ above Fallen Leaf Lake, were measured at $21 \mathrm{ppb}$ during high discharge in late June 2011.

\section{Interannual Variation}

Over the 3-year monitoring period, there was a fair degree of variability in winter precipitation, spring temperature, and the strength and timing of stratification. The variability of these environmental attributes provides an interesting backdrop with which to consider the interannual variability in phytoplankton composition. To provide some perspective for evaluating the variability in the past 3 years of monitoring data, all previously published transparency, precipitation, and temperature data have been plotted back to water year 1970 (Fig. 7), when data was first collected for Fallen Leaf Lake by Goldman (Reuter et al. 1993). Both 2009 and 2010 showed average winter precipitation (Fig. 7), but the spring of 2010 was cooler than the preceding year, and stratification was delayed by about a month. As a result, the 1 July 2010 sampling shows a chlorophyll maximum at $12.5 \mathrm{~m}$, which later descended to $40 \mathrm{~m}$ by the time of the second 2010 sampling in September. In contrast, 2011 was a heavy precipitation year, and a deep snowpack coupled with cool spring temperatures delayed spring runoff. In late June 2011, the upper parts of the watershed were still covered with snow, and there was considerable inflow from Glen Alpine Creek that persisted through July. In 2011, the DCM was shallower, centered at $30 \mathrm{~m}$ in early September. The shallower position of the DCM 2011 may best be explained by lower transparency, as Secchi depths were shallower in 2011 than in preceding years (Table 1, Fig. 7).

Diatom data from our 3 field seasons show variation in the dominant species, alternating between Tabellaria flocculosa strain IIIp (2009), Asterionella formosa (2010), and Fragilaria tenera-group (2011; Fig. 8). Tabellaria flocculosa strain IIIp distribution in the water column tracked seasonally with As. formosa, but its abundance was highly variable between seasons. Tabellaria flocculosa strain IIIp was the most dominant diatom in 2009 , and its peak abundance, centered in the DCM in midsummer, exceeded $150 \mu \mathrm{m}^{3} \cdot \mathrm{L}^{-1}$. Though still present in 2010 and 2011, T. flocculosa strain IIIp was comparatively rare, peaking at $4 \mu \mathrm{m}^{3} \cdot \mathrm{L}^{-1}$ in 2010 and $15 \mu \mathrm{m}^{3} \cdot \mathrm{L}^{-1}$ in 2011. Fragilaria tenera-group also showed marked seasonal variation, dominating the epilimnion in the early spring bloom and then dropping off in the summer. In 2011, F. tenera-group was the dominant species, exceeding $95 \mathrm{\mu m}^{3}$. $\mathrm{L}^{-1}$ in the epilimnion in the spring, and its large numbers may have contributed to the lower transparency. Snapshots from the early 1990s also indicate interannual variation in the dominant phytoplankton species; however, there are insufficient data to discern long-term trends or patterns. In May 1991, planktonic Tabellaria identified as T. fenestrata (56\%) and Au. subarctica (28\%) were the dominant diatoms, and As. formosa and F. tenera group (identified as Synedra radians) were minor components (Reuter et al. 1993). In contrast, planktonic Tabellaria was a minor component in the 1994 spring bloom, which at its peak in May was dominated by Cyclotella rossii, identified as C. kutzingiana ( $>50 \%$ ), followed by F. tenera-group (25\%) and As. formosa (20\%) (Reuter et al. 1996)

In the context of winter precipitation data, it is tempting to attribute increased Fragilaria tenera in 2011 to an increase in DIN load entering the lake. Fragilaria tenera-group shows a strong response in the early spring when $\mathrm{NO}_{3}$ is highest. Unfortunately, there are no experimental data on the response of $F$. tenera-group to $\mathrm{N}$ stimulation, and this relationship is at best equivocal when the limited previous phytoplankton monitoring data are examined. There were slightly elevated abundances of $F$. tenera-group in 1994 relative to 1991 (Reuter et al. 1996), but both years were relatively dry (Fig. 7). In 1994, Lake Tahoe received $711 \mathrm{~cm}$ of precipitation, compared to $2057 \mathrm{~cm}$ in 2011. Calculated DIN loads for South Lake Tahoe for 1994 were $~ 1200 \mathrm{~g}$ • $\mathrm{ha}^{-1}$, slightly lower than the 1991 loads (TERC 2011). It is possible that the rate of snowmelt and episodicity of nutrient pulses may be factors in species dominance through resource competition. Such was indicated by a culture experiment that simulated a P-limiting system with varied frequency of nutrient additions over a 35-d period (Suttle et al. 1987). All 

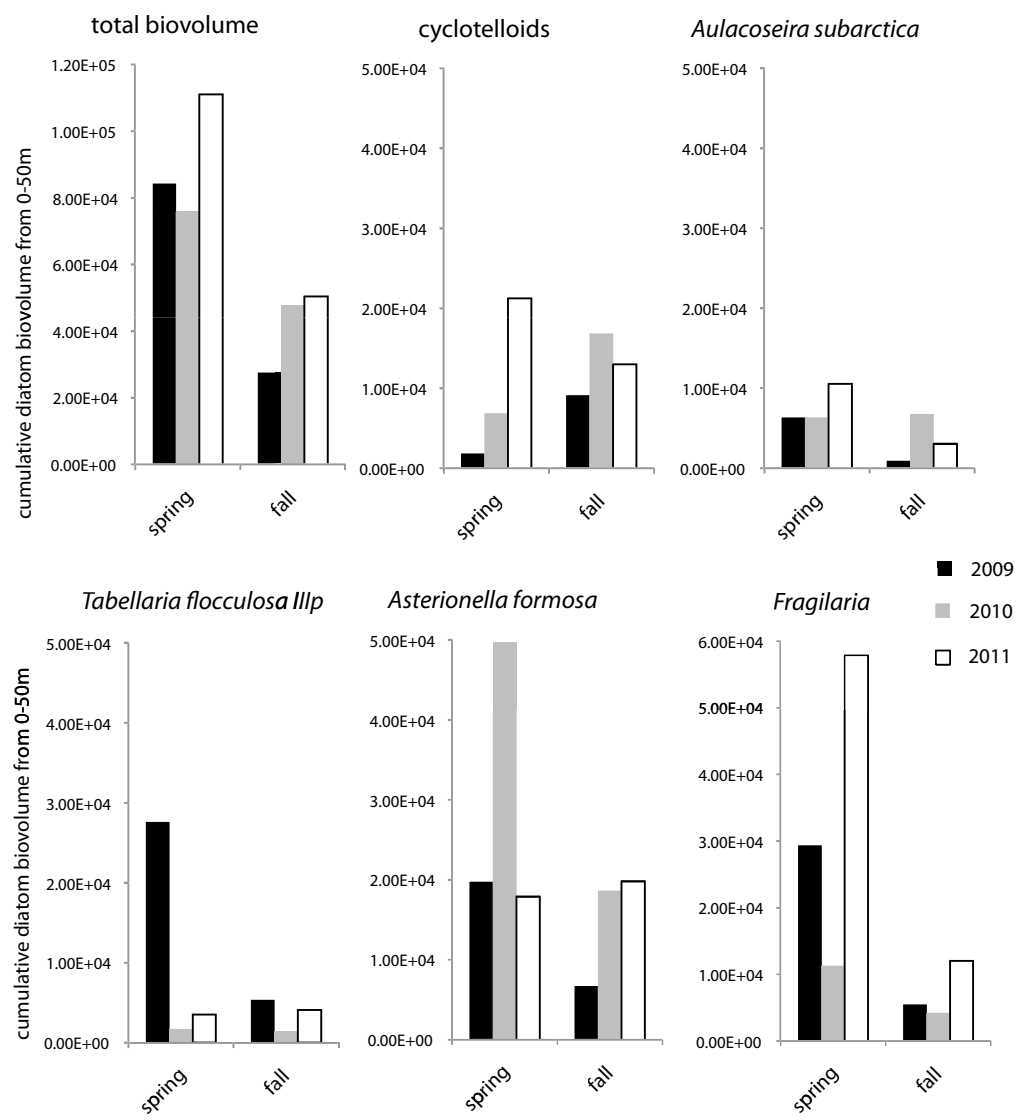

Fig. 8. Interannual variability in diatom biovolume at Fallen Leaf Lake, California. Tabellaria flocculosa strain IIIp was the most dominant species in 2009, Asterionella formosa in 2010, and Fragilaria tenera-group in 2011. Cumulative biovolume respresents the sum of biovolume $\left(\mu \mathrm{m}^{3} \cdot \mathrm{mL}^{-1}\right)$ from 10 depths counted from 0 to $50 \mathrm{~m}$ for each sampling period.

cultures received the same total amount of nutrients over the course of the experiment, yet those receiving additions every 4 and 8 days were dominated by a planktonic species identified as Synedra radians. Those with less frequent additions every 16 days were dominated by $T$. fenestrata. The potential relationship between species dominance and resource fluctuations for T. flocculosa strain IIIp versus F. tenera-group and/or A. formosa is intriguing and awaits testing in an $\mathrm{N}$-limited system where nutrient influx is related to patterns of spring temperature snowmelt flux.

\section{Cyclotelloid Distribution}

A marked partitioning was observed between the 2 live species of cyclotelloids, namely Cyclotella rossii and Handmannia bodanica, both of which are common planktonic taxa in oligotrophic lake systems. Cyclotella rossii was found in high abundances in the early spring, but was reduced in the eplimnion relative to $H$. bodanica during the stratification period. Cyclotella rossii numbers peaked in midsummer in the hypolimnion within the DCM. These spatial and seasonal variations are intriguing and may potentially be useful in discriminating stratification patterns in the fossil record. As a test, valve counts of the 2 cyclotelloid species were made from discrete water samples taken at depths of $0,10,20$, and $50 \mathrm{~m}$, as well as from the composite vertical plankton tows, from early June through September 2009 (Fig. 9). Composite counts made from the 70-m vertical plankton tows presumably show how the discrete partitioning is collapsed into the bottom sediment. There is a pronounced difference between early spring 
6-1-09

9-25-09

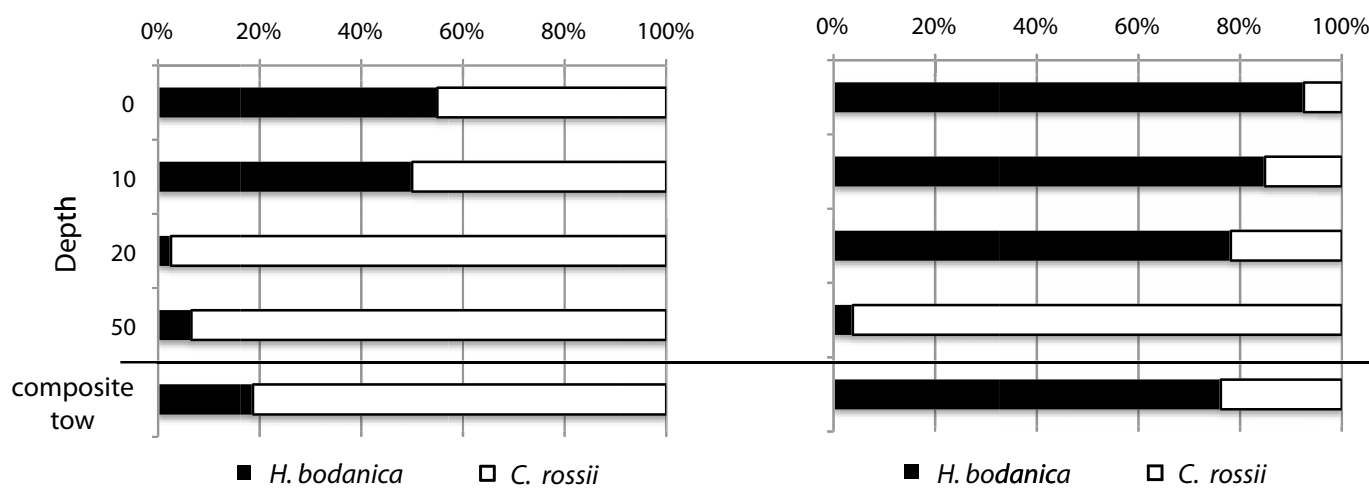

Fig. 9. Relative percentage of valves of the 2 live cyclotelloid species, Handmannia bodanica and Cyclotella rossii, as counted from 4 water depths $(0,10,20$, and $50 \mathrm{~m})$ and from $70-\mathrm{m}$ vertical composite tows at Fallen Leaf Lake, California. In the spring (left), C. rossii represents roughly half of the epilimnetic valves and dominates the deeper samples. In the summer and early fall (right), H. bodanica dominates the epilimnion and upper hypolimnion. In both cases, the composite tows reflect each species' dominance.

(1 June and 26 June), when $H$. bodanica composed $<20 \%$ of the valves in the composite tow, and mid to late summer, when $H$. bodanica accounted for $>75 \%$ of the valves in the composite tow. Given the magnitude of the difference, it is logical to assume this ratio may be an effective proxy for the degree and duration of the stratification period, with higher percentages of $H$. bodanica relative to $C$. rossii representing years with stronger stratification.

The mixing depth, or depth of the epilimnion, has recently been linked to cyclotelloid species composition in P-limited oligotrophic lakes (Saros et al. 2012). Handmannia bodanica was shown to be dominant in lakes with greater mixing depths $(14 \mathrm{~m})$ than 2 other common cyclotelloid species inhabiting the suite of lakes studied, namely Cyclotella comensis and D. stelligera (Saros et al. 2012). Cyclotella comensis is part of the same species complex that includes $C$. rossii. Though our data show the potential for linking changes in the duration and depth of stratification with fossil cyclotelloid composition, the Saros et al. (2012) study indicates that long-term changes to lake thermal structure may also play a role in variations of cyclotelloid dominance, with stronger epilimnetic development favoring $H$. bodanica.

\section{SUMMARY}

Monitoring data from 2009 to 2012 show that the Fallen Leaf Lake phytoplankton community is currently dominated by the araphid species Asterionella formosa, Tabellaria flocculosa strain IIIp, Fragilaria tenera-group, and F. gracilis, with lesser amounts of Aulacoseria (chiefly Au. subarctica), cyclotelloids (Cyclotella rossii and Handmannia bodanica), Urosolenia eriensis, and Nitzschia. There is a strong seasonal component that favors Aulacoseria and Nitzschia in the winter through early spring, shows short-lived peaks in F. tenera-group and $U$. eriensis in the spring bloom, and exhibits more persistent numbers of As. formosa and T. flocculosa strain IIIp through the spring and summer. Stratification results in a strong vertical partitioning of diatom species and the development of a deep chlorophyll maximum (DCM) that is centered in the hypolimnion between 30 and $40 \mathrm{~m}$. The depth of the DCM appears to be related to light availability, as it was shallower in 2011 when Secchi depths were also shallower. Aside from winter production, the largest volume of diatom productivity is associated with the DCM. The DCM also shows a seasonal succession, with $C$. rossii becoming increasingly dominant in late summer and early fall. Strong vertical partitioning of cyclotelloid species is observed where $H$. bodanica increases from $<20 \%$ to $>75 \%$ of the valves in the composite water column. Ratios of $H$. bodanica to $C$. rossii may be a useful down-core proxy in gauging strength of past stratification.

Chronically high percentages of Asterionella formosa were documented for all 3 years, and 
this species appears to be abundant yearround, moving into the meta- and hypolimnion during stratification. It will be important to examine its distribution down core to determine whether As. formosa abundance is a recent phenomenon in response to atmospheric $\mathrm{N}$ deposition, as has been proposed in other temperate N-limiting lake systems. Interannual variability was observed in the dominant diatom species. In all 3 years, the dominant species was an araphid but alternated between Tabellaria flocculosa strain IIIp, As. formosa, and Fragilaria tenera-group. Similarly, data from the early 1990s showed alternating dominance by araphid species and by Cyclotella rossii in one year. The years 2009-2011 varied widely in terms of winter precipitation, spring temperature, runoff and nutrient influx, and onset and strength of stratification. Unfortunately, there are insufficient data and too many variables to presently tie the variation in dominant species to any of these factors. Future long-term monitoring, as well as experimental work on resource requirements and nutrient response of $T$. flocculosa strain IIIp and F. tenera-group, will be needed to determine the principal causes of interannual variation in the dominant araphid species. Finally, a significant component of the valves found in winter and early-spring water samples are washed-in littoral, stream, and marsh species from higher in the watershed. There are negligible areas of periphyton growth in the lake today, and identification of the washed-in components will be useful in down-core reconstructions.

\section{ACKNOWLEDGMENTS}

We thank C. Ngai, A. Menicucci, A. Louie, Y. Jin, S. O’Connor, N. Noble, L. Stratton, and B. Johnson, who assisted with monitoring and water processing at various times throughout the project. We thank B. Eustis, who ran our chlorophyll $a$ analyses. We also thank Deb Hunter for helpful discussions and assistance in harmonizing taxonomy with previous algal data generated by TERC at UC Davis, as well as S. Spaulding, K. Ruhland, M. Julius, J. Saros, and J. Stone for productive discussions on diatom ecology and taxonomy. This work was funded internally through the Biostratigraphy Lab and Limnology Lab at UNR.

\section{Literature Cited}

Akima, H., A. Gebhardt, T. Petzoldt, and M. MaechLER. 2012. Akima: interpolation of irregularly spaced data, $R$ package version 0.5-7. Available from: http://CRAN.R-project.org/package= akima

Barbiero, R.P., and M.L. Tuchman. 2004. The deep chlorophyll maximum in Lake Superior. Journal of Great Lakes Research 30 (Supplement 1):256-268.

Battarbee, R.W. 1986. Diatom analysis. Pages 527-570 in B.E. Berglund, editor, Handbook of Holocene Palaeoecology and Palaeohydrology. J. Wiley \& Sons, Inc., New York, NY.

Brothers, D.S., G. Kent, N.W. Driscoll, S.B. Smith, R. Karlin, J.A. Dingler, A.J. Harding, G.G. Seitz, AND J.M. BABCOCK. 2009. New constraints on deformation, slip rate, and timing of the most recent earthquake on the West Tahoe-Dollar Point Fault, Lake Tahoe Basin, California. Bulletin of the Seismological Society of America 99(2A):499-519.

Camburn, K.E., and J.C. Kingston. 1986. The genus Melosira from soft-water lakes with special reference to northern Michigan, Wisconsin and Minnesota. Pages 17-36 in J.P. Smol, R.W. Battarbee, R.B. Davis, and J. Meriläinen, editors, Diatoms and lake acidity. Dr. W. Junk Publishers, Dordrecht, Netherlands.

Camacho, A. 2006. On the occurrence and ecological features of deep chlorophyll maxima (DCM) in Spanish stratified lakes. Limnetica 25(1-2):453-478.

CARLSON, R.E. 1977. A trophic state index for lakes. Limnology and Oceanography 22:361-369.

1983. Discussion on "Using differences among Carlson's trophic state index values in regional water quality assessment," by Richard A. Osgood. Water Resources Bulletin 19:307-309.

Carlson, R.E., and J. Simpson. 1996. A coordinator's guide to volunteer lake monitoring methods. North American Lake Management Society. 96 pp.

Coon, T.G., M.M. Lopez, P.J. Richerson, T.M. Powell, AND C.R. Goldman. 1987. Summer dynamics of the deep chlorophyll maximum in Lake Tahoe. Journal of Plankton Research 9(2):327-344.

Chandra, S., AND A. Rost. 2008. Nutrients and clarity of subalpine lakes in the upper Lake Tahoe watershed during early summer. Presented at the 4th Biennial Tahoe Basin Science Conference: Science as a tool in Lake Tahoe Basin management: making sense of complexity. Incline Village, NV.

Florin, M.B. 1981. The taxonomy of some Melosira species, a comparative morphological study. II. Proceedings of the 6th Symposium on Recent and Fossil Diatoms, Budapest, Hungary. Koeltz, Koenigstein, Germany.

FULLER, R.H. 1975. Selected water-quality data from Fallen Leaf Lake, El Dorado County, California, June through October 1974. U.S. Geological Survey Open File Report, November 1975. 38 pp.

Goldman, C.R. 1970. Limnological conditions in Fallen Leaf Lake and its effluent stream. Unpublished report.

Goldman, C.R., R.P. Axler, and J.E. Reuter. 1983. Fallen Leaf Lake, California-water quality survey July 1983. Unpublished report.

Hanes, T. 1981. Hydrologic analysis of the Fallen Leaf Lake watershed and operational plan for Fallen 
Leaf Lake. U.S. Forest Service Region 5 Lake Tahoe Basin Management Unit. 50 pp.

Harrison, J.W., AND R.E. Smith. 2011. Deep chlorophyll maxima and UVR acclimation by epilimnetic phytoplankton. Freshwater Biology 56:980-992.

Haworth, E.Y. 1988. Distribution of diatom taxa of the old genus Melosira (now mainly Aulacoseira) in Cumbrian waters. Pages 133-167 in F.E. Round, editor, Algae and the aquatic environment. Biopress Ltd., Bristol, England.

Hillebrand, H., C.D. Durselen, D. Kirschtel, U. Pollingher, and T. Zohary. 1999. Biovolume calculation for pelagic and benthic microalgae. Journal of Phycology 35(2):403-424.

Interlandi, S.J., S.S. Kilham, and E.C. Theriot. 1999. Responses of phytoplankton to varied resource availability in large lakes of the Greater Yellowstone Ecosystem. Limnology and Oceanography 44(3):668-682.

KLEPPE, J.A. 2005. A study of ancient trees rooted $36.5 \mathrm{~m}$ $\left(120^{\prime}\right)$ below the surface level of Fallen Leaf Lake, California. Journal of the Nevada Water Resources Association 2(1):29-40.

Lico, M.S. 2004. Nutrient concentrations in Upper and Lower Echo, Fallen Leaf, Spooner, and Marlette lakes and associated outlet streams, California and Nevada, 2002-03. USGS Open-File Report 2004: 1333.

Moll, R.A., And E.F. Stoermer. 1982. A hypothesis relating trophic status and subsurface chlorophyll maxima of lakes. Archiv für Hydrobiologie 94: $425-440$.

[NRCS] Natural Resources Conservation Service. 2012. Standard SNOTEL historic data tables for SNOTEL site FALLEN Leaf (473), daily series data by wateryear report, National Climate and Water Center, U.S. Department of Agriculture, National Resources Conservation Service; [cited 3 July 2012].

Parsons, T.R., Y. Maita, and C.M. LaLLi. 1984. A manual of chemical and biological methods for seawater analysis. Pergamon Press, New York, NY.

PRISM Climate Group. 2012. Home page: PRISM Climate Group. Oregon State University, Corvallis, OR; [cited 1 January 2012]. Available from: http://prism .oregonstate.edu

R Development Core Team. 2012. R: a language and environment for statistical computing. R Foundation for Statistical Computing, Vienna, Austria. ISBN: 3900051-07-0. Available from: http://www.R-project.org

Reuter, J.E., A. Hayveart, and C.R. Goldman. 1990. Evaluation of water quality conditions in Fallen Leaf Lake, California with special emphasis on trophic status, phytoplankton species composition, and concentration of heavy metals in water and biota. Division of Environmental Studies, University of California, Davis, CA. 43 pp.

Reuter, J.E., M.D. Palmer, and C.R. Goldman. 1996. Limnology and trophic status of Lower Echo Lake, Upper Echo Lake, and Fallen Leaf Lake. Tahoe Research Group, University of California, Davis, CA.

Reuter, J.E., R.C. Richards, and C.R. Goldman. 1993. Evaluation of limnological conditions in Fallen Leaf
Lake, California with recommendations for updated water quality objectives and control measures. Institute of Ecology and Division of Environmental Studies, University of California, Davis, CA. 44 pp.

Reynolds, C.S. 2006. The ecology of phytoplankton. Cambridge University Press, Cambridge, England. $535 \mathrm{pp}$.

1992. Dynamics, selection and composition of phytoplankton in relation to vertical structure in lakes. Archiv für Hydrobiologie Beihefte Ergebnisse der Limnologie 35:13-31.

1984. The ecology of freshwater phytoplankton. Cambridge University Press, Cambridge, England. 384 pp.

1980. Phytoplankton assemblages and their periodicity in stratifying lake systems. Holarctic Ecology 3:141-159.

Saros, J.E., S.J. Interlandi, A.P. Wolfe, and D.R. ENGSTROM. 2003. Recent changes in the diatom community structure of lakes in the Beartooth Mountain Range, U.S.A. Arctic, Antarctic, and Alpine Research 35:18-23.

Saros, J.E., T.J. Michel, S.J. Interlandi, AND A.P WOLFE. 2005. Resource requirements of Asterionella formosa and Fragilaria crotonensis in oligotrophic alpine lakes: implications for recent phytoplankton community reorganizations. Canadian Journal of Fisheries and Aquatic Sciences 62:1681-1689.

Saros, J.E., J.R. Stone, G.T. Pederson, K.E.H. Slemmons, T. Spanbauer, A. Schliep, D. Cahl, C.E. Williamson, and D.R. Engstrom. 2012. Climateinduced changes in lake ecosystem structure inferred from coupled neo- and paleoecological approaches. Ecology 93:2155-2164.

Sommer, U. 1985. Seasonal succession of phytoplankton in Lake Constance. Bioscience 35:351-357.

Suttle, C.A., J.G. Stockner, and P.J. Harrison. 1987. Effects of nutrient pulses on community structure and cell size of a freshwater phytoplankton assemblage in culture. Canadian Journal of Fisheries and Aquatic Sciences 44:1768-1774.

[TerC] Tahoe Environmental Research Center. 2011. Tahoe: State of the Lake Report. Tahoe Environmental Research Center, University of California, Davis, CA.

[USEPa] United States Environmental Protection AGENCY. 1973. Biological field and laboratory methods for measuring the quality of surface waters and effluents. EPA-670/4-73-001, U.S. Environmental Protection Agency Office of Research and Development, Cincinnati, $\mathrm{OH}$.

Welschmeyer, N.A. 1994. Fluorometric analysis of chlorophyll $a$ in the presence of chlorophyll $a$ and phaeopigments. Limnology and Oceanography 39: 1985-1993.

WetzeL, R.G. 2001. Limnology: lake and river ecosystems. 3rd edition. Academic Press (Elsevier), San Diego and London. 1006 pp.

Received 31 December 2012 Accepted 29 May 2013 

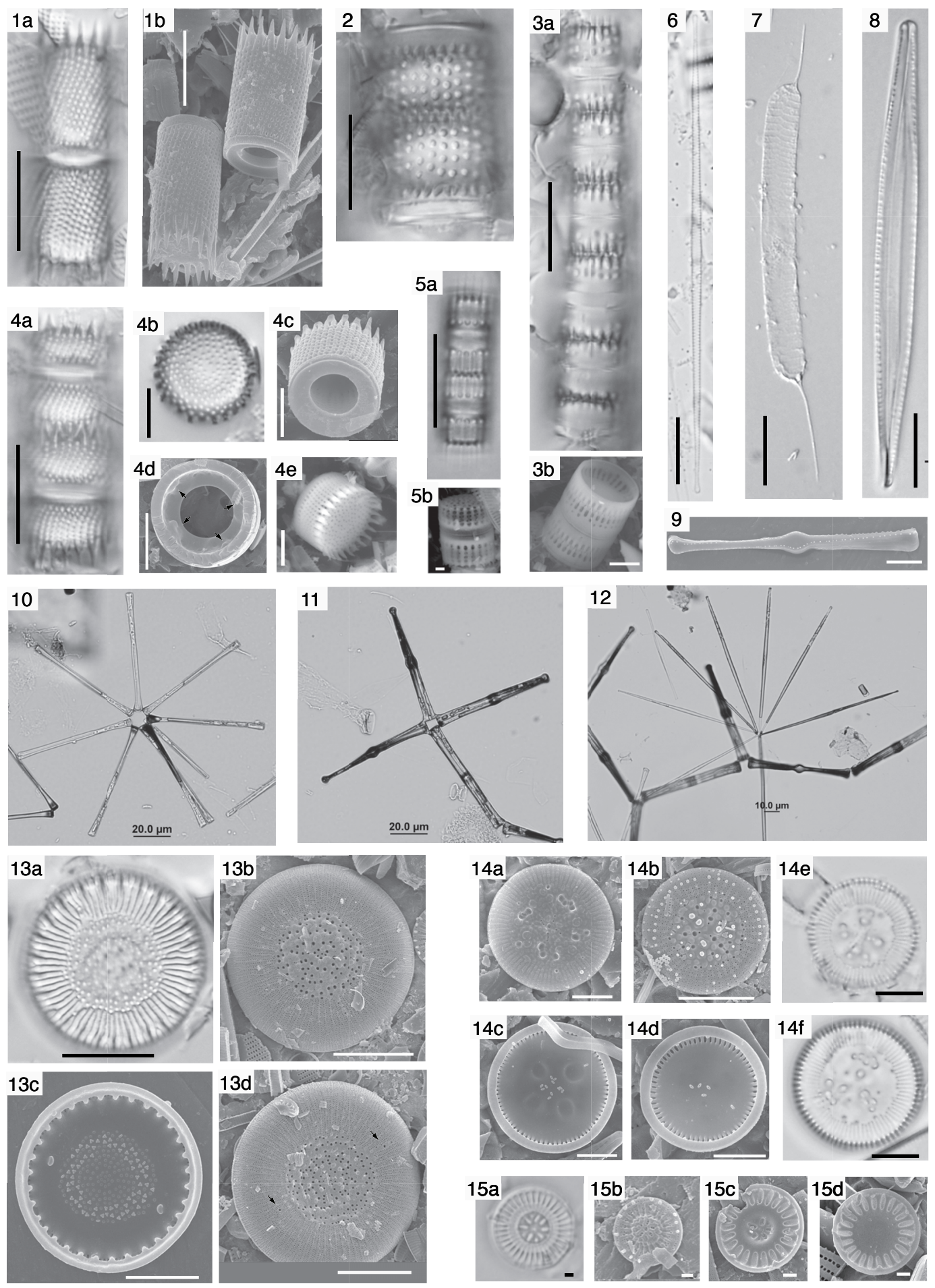
Appendix (FIgURE ON FACING PAGE).-Diatom photomicrographs and taxonomic notes. Transmitted light and scanning electron photomicrographs were taken of diatoms from water samples and surface sediment from Fallen Leaf Lake, Sierra Nevada, California. Transmitted light photos taken with plane-polarized light are specified as "nonDIC" and those taken with a differential interference contrast filter are specified as "DIC." Scanning electron images taken with an Hitachi-SM1000 tabletop SEM are specified as "SEM-ENV" and those taken wih a JEOL JSM-6700-F field emission SEM are specified as "SEM-FE."

1. Aulacoseira subarctica (Müller) Haworth 1988.

a, DIC surface sediment, scale $=10 \mu \mathrm{m} ; \mathbf{b}$, SEM-FE surface sediment, scale $=10 \mu \mathrm{m}$.

Taxonomic notes: Specimens commonly with a diameter of $7 \mu \mathrm{m}$, long mantle height, valve face imperforate, 1 spine per 2 rows of costae.

2. Aulacoseira lirata (Ehrenberg) Ross in Hartley 1986.

DIC surface sediment, scale $=10 \mu \mathrm{m}$.

Taxonomic notes: Diameter commonly $>10 \mu \mathrm{m}$, collum is prominent, coarse round areolae in straight rows, 1 spine per row of costae, imperforate flat valve face, deep ringleiste.

3. Aulacoseira perglabra (Østrup) Haworth 1988.

a, DIC surface sediment, scale $=10 \mu \mathrm{m} ; \mathbf{b}$, SEM-ENV surface sediment, top view is into valve interior, scale $=5 \mu \mathrm{m}$.

Taxonomic notes: Diameter commonly $6-8 \mu \mathrm{m}$, low mantled, mantle areolae are rare and sporadic in transmitted light, 1 row at peripheral margin below spine insinuation is variably developed, long linking spines, no ringleiste, valve face imperforate, concave.

4. Aulacoseira pusilla (Meister) Tuji \& Houki 2004.

a, DIC surface sediment, scale $=10 \mu \mathrm{m} ; \mathbf{b}$, nonDIC of valve face from surface sediment, scale $=5 \mu \mathrm{m} ; \mathrm{c}, \mathrm{SEM}-\mathrm{FE}$ surface sediment showing external view of ringleiste, linking spines also visible, scale $=5 \mu \mathrm{m} ; \mathbf{d}$, SEM-FE surface sediment showing internal view of ringleiste, rimoportulae are marked with arrows, scale $=5 \mu \mathrm{m}$; e, SEMENV showing perforate valve face and linking spines, scale $=5 \mu \mathrm{m}$.

Taxonomic notes: Diameter $\geq 7 \mu \mathrm{m}$, valve-tomantle ratio of $1: 1$ or less. Valve face is flat and ranges from densely perforate to sparse and irregularly punctate. Linking spines same structure as $A u$. subarctica, except commonly shorter and blunter, ringleiste deep, 4-6 rimoportulae on ringleiste are observable in valve view.

5. Aulacoseira humilis (Cleve-Euler) Genkal \& Trifanova in Trifanova \& Genkal 2001.

$\mathbf{a}$, DIC surface sediment, scale $=10 \mu \mathrm{m} ; \mathbf{b}$, SEM-ENV surface sediment, scale $=1 \mu \mathrm{m}$.

Taxonomic notes: Small diameter, commonly 5 $\mu \mathrm{m}$, small double rows of mantle areolae set in straight grooves gives striped appearance in mantle view, mantle costae prominent, 1 long and thin linking spine per costa, valve face coarsely punctate.

6. Fragilaria nanana Lange-Bertalot 1991, included in Fragilaria tenera-group.

Valve view, nonDIC from cleaned surface water sample, scale bar $=10 \mu \mathrm{m}$.

Taxonomic notes: Long and thin, 40-90 $\mu \mathrm{m}$, 1.5-2 $\mu \mathrm{m}$ diameter, apices slightly capitate, striae straight and appear to alternate, varying from 19-24 $\mu \mathrm{m}$ (commonly $22-23 \mu \mathrm{m}$ ) in live specimens, which fits $F$. nanana striae counts $(21-24 / 10 \mu \mathrm{m})$. Fragilaria tenera (W. Smith) Lange-Bertalot 1980 has fewer striae $(17-20 / 10 \mu \mathrm{m})$. Shorter specimens (30-35 $\mu \mathrm{m}$ length), encountered in water samples, that did not taper as much apically and were $2 \mu \mathrm{m}$ wide were assigned to $F$. gracilis Østrup 1910. All 3 species were enumerated within the $F$. tenera group in water samples because they are difficult to discriminate at $400 \mathrm{X}$ in a Sedgewick-Rafter counting cell.

7. Urosolenia eriensis (H.L. Smith) Round \& Crawford in Round, Crawford, and Mann 1980.

DIC from water spring surface sample, scale bar $=10 \mu \mathrm{m}$

\section{Nitzschia sp.}

Live specimen from winter surface water sample, nonDIC, scale bar $=10 \mu \mathrm{m}$.

9. Tabellaria flocculosa strain IIIp sensu Koppen 1975.

SEM-FE from a spring water sample.

Taxonomic notes: Commonly 50-60 $\mu \mathrm{m}$ long, slight torsion in valves, apices capitate and may appear asymmetrical. Fine marginal spines observable in SEM and transmitted light, median inflation only slightly wider than apices, copulae complete and with a rudimentary septum.

\section{Asterionella formosa Hassall 1850.}

Live colony from spring water sample, nonDIC, always forms stellate colonies, scale bar $=20 \mu \mathrm{m}$.

11. Tabellaria flocculosa strain IIIp sensu Koppen 1975.

Live material from spring water sample, nonDIC, forms colonies, scale bar $=20 \mu \mathrm{m}$.

12. Fragilaria tenera group and T. flocculosa strain IIIp.

Stellate colony typical in F. tenera group (likely $F$. nanana), scale bar $=10 \mu \mathrm{m}$.

13. Handmannia bodanica (Eulenstein ex Grunow) Kociolek \& Khursevich in Khursevich and Kociolek 2012.

a, Cleaned specimen from surface water sample, DIC, scale bar $=10 \mu \mathrm{m} ; \mathbf{b}$, SEM-FE from surface sediment, scale bar $=10 \mu \mathrm{m}$; c, SEM-FE from water sample, view of inner valve face showing Schattenlinie at margin, 2 rimoportulae, and distribution of cribrate areolae and fultoportulae, scale 
bar $=10 \mu \mathrm{m} ; \mathbf{d}$, SEM-FE from surface sediment openings of rimoportulae indicated with arrows, scale bar $=10 \mu \mathrm{m}$.

Taxonomic notes: Valve 18-25 $\mu$ m diameter, face with slight concentric undulation. Valve center with numerous areolae and fultoportulae, annulus absent, valve margin striate, some forked striae branch at margin, with 2 rimoportulae. In SEM, 2 rimoportulae appear as enlarged pores in marginal area of valve face, both with labiate processes on inner valve face. Central fultoportulae with 3 satellite pores, and areolae with internal cribra. In terms of varieties, none is specified at this time. The pattern of striae and areolae, and the disposition of mantle rimoportuale and fultoportulae vary from the nominate variety, as well as from $v$. affinis and $v$. intermedia.

14. Cyclotella rossii Håkansson 1990.

$\mathbf{a}$ and $\mathbf{b}$, external views of valve SEM-FE from surface sediment, note differences in ornamentation of central area, scale bar $=5 \mu \mathrm{m}$; $\mathbf{c}$, and $\mathbf{d}$, SEM-FE from surface sediment, internal views of valve faces showing Schattenlinie at margin, rimoportulae, and several fultoportulae at center, scale bar $=5 \mu \mathrm{m}$.

Taxonomic notes: Valve diameter 8-20 $\mu \mathrm{m}$, valve face fairly flat, central area highly variable with ornamentation of variable size and arrangement, may be ocellate, with 3-4 ocellae. Several fultoportulae in central area, and 1 rimoportula present in center of marginal area, rimoportulae seen on inner valve face, and central fultoportulae with 2 satellite pores. It is unclear whether this is one highly variable species or multiple species within a species group.

15. Discostella stelligera (Cleve \& Grunow) Houk \& Klee 2004.

a, DIC from cleaned water sample, scale bar $=1$ $\mu \mathrm{m}$; b, SEM-FE external stellate valve face from surface sediment, scale bar $=1 \mu \mathrm{m}$; c, SEM-FE internal view of stellate valve face from surface sediment, scale bar = 1 um; d, SEM-FE internal view of nonstellate valve face from surface sediment.

Taxonomic notes: Valves small, usually $<10 \mu \mathrm{m}$, may be polymorphic with one stellate and one nonstellate valve. 